\title{
Abraham Lincoln and the Triumph of an Antislavery Nationalism
}

\section{GRAHAM ALEXANDER PECK}

The ascension of the 1850s Republican Party remains one of the most remarkable and significant developments in American political history. Never before or since has a third party displaced a preexisting major party, and never before or since has the success of any party resulted in the almost instantaneous and near-fatal trauma that beset the American nation in 1860. For those reasons alone the party's genesis remains an issue of enduring historical interest. Yet the party's early history is also engrossing in its own right. Perhaps most astonishing was the speed of the Republican revolution. Only two years after its initial organization, and in its first national campaign, the party dominated its two northern rivals. It achieved that success despite competition from a nativist party, bitter opposition from northern Democrats, serious intraparty divisions, and inadequate organization. Of "strange, discordant, and even, hostile elements," Lincoln recalled in 1858, "we gathered from the four winds" with "every external circumstance against us." Nevertheless, Lincoln claimed the presidency in 1860 because the Republicans won every northern state. That achievement was also remarkable. After all, northerners had long resisted antislavery politics because they feared its disunionist consequences. They rightly perceived it as a radical innovation on established political practice, and thus they had largely withheld their support from antislavery parties. How the Republicans managed so rapidly to invert northern ideas about antislavery politics is thus an issue of considerable importance. ${ }^{1}$

Yet historians are sharply divided in their explanations about how the Republican Party achieved its success. In his seminal book on

1. Roy P. Basler et al., eds., The Collected Works of Abraham Lincoln, 9 vols. (New Brunswick, N.J.: Rutgers University Press, 1953-1955): 2:468. The obstacles to the party's survival in its first two years caused its leading chronicler to portray its triumph in 1856 as something of a miracle. William E. Gienapp, Origins of the Republican Party, 1852-1856 (New York: Oxford University Press, 1987), vii-viii, 443-48. I am grateful to Jared Orsi, Adam I. P. Smith, Daniel Feller, Richard Carwardine, and an anonymous reviewer for suggestions that markedly improved this essay. 
free labor, Eric Foner contended that the Republican Party's ideology emerged from the worldview of a northern bourgeois class committed to the idea of social mobility and hence hostile to slavery and critical of southern society. This argument rooted ideological and political conflict in the fundamental economic differences of southern and northern society. Yet Foner's argument, despite its justly deserved influence, is not entirely persuasive. After all, like Republicans, northern Democrats lived in northern society, valued social mobility, celebrated progress, and participated extensively in market exchange. Yet they bitterly opposed Republican Party antislavery politics, which suggests that Republican advocacy of free labor was not the primary factor differentiating the northern parties in the 1850s. If free labor did not differentiate them, what did? A focus on free labor also makes it difficult to adequately explain how Republicans secured swing voters in the 1860 election. That election turned in part on Lincoln's ability to attract Whigs who had voted for the nativist American Party in 1856, but who hesitated to vote for an antislavery party because they feared disunion. On the slavery question, those voters tended toward conservatism, or advocacy of sectional conciliation and peace. However, free labor appeals had long generated severe criticisms of slavery and southern society, and had been intensively used by abolitionists since the 1830s. For that reason free labor doctrine was not ideally suited to attract nervous northern Whigs. How, then, did Republicans secure swing voters in the crucial 1860 election? These two questions suggest that free labor is a necessary but not a sufficient explanation for the rise and triumph of the Republican Party. ${ }^{2}$

William Gienapp and Michael Holt have offered alternative expla-

2. Foner, Free Soil, Free Men, Free Labor: The Ideology of the Republican Party Before the Civil War (New York: Oxford University Press, 1970); Gienapp, Origins of the Republican Party, 357; Gienapp, "Who Voted for Lincoln," in Abraham Lincoln and the American Political Tradition, ed. John L. Thomas (Amherst: University of Massachusetts Press, 1986), 52-54; Michael F. Holt, "Making and Mobilizing the Republican Party, 1854-1860," in The Birth of the Grand Old Party: The Republicans' First Generation, ed. Robert F. Engs and Randall M. Miller (Philadelphia: University of Pennsylvania Press, 2002), 29-59. Gienapp also criticized Foner for slighting the years 1854 to 1856 and consequently overemphasizing the significance of free labor to early Republican Party ideology. Although not addressing that critique directly, this essay does trace the development of Lincoln's thought from the inception of the anti-Nebraska movement in 1854 until 1860, and shows how Lincoln was able to seamlessly weave free labor ideas into his nationalist appeals. Gienapp, Origins of the Republican Party, 357, n. 44. A recent new defense of the free labor position is James L. Huston, Calculating the Value of the Union: Slavery, Property Rights, and the Economic Origins of the Civil War (Chapel Hill: University of North Carolina Press, 2003), 67-103. 
nations of Republican Party ideology. Gienapp argued that Republican ideology focused primarily on fear of the southern Slave Power-a slaveholding aristocracy that controlled both the southern states and the federal government. Gienapp's interpretation of Republican ideology was part of his broader argument that the rise of the Republican Party stemmed primarily from the political upheaval caused by nativism and temperance reform at the state level in the early 1850s, combined with the subsequent actions of ambitious northern politicians who demonized the South. By his logic, fundamental differences between the North and South were not to blame for the political conflict. Advancing a similar but not identical argument, Michael Holt has maintained that the Republicans objected primarily to the political power of slaveholders, not to slavery per se. Republicans feared that the slaveholders' domination of the federal government threatened to undermine the liberty of white men in the North. Gienapp and Holt offer an explanation for what differentiated Democrats from Republicans and for why Republicans secured swing voters in 1860; after all, northern Democrats generally did not fear slaveholder political power, and conservative northerners had good reason to vote Republican to protect their rights. Nevertheless, Gienapp and Holt have their own critics, most notably Kenneth Stampp, who observed that it is difficult to imagine how Republicans could have been so hostile to slaveholders without also having been hostile to the source of the slaveholders' political power: slavery. And if Republicans sharply opposed both slavery and the Slave Power, then the argument that the Civil War was not rooted in fundamental causes loses much of its persuasiveness. For these reasons, the ideological appeal of the Republican Party in the 1850s deserves re-examination. This requires us to return to Abraham Lincoln. ${ }^{3}$

This paper contends that Lincoln and the Republicans inverted northern ideas about antislavery politics by attaching a powerful nationalist ideology to the antislavery movement. Their core proposition-that the nation was dedicated to freedom-resonated deeply in the free states.

3. Gienapp, Origins of the Republican Party, 347-73; Gienapp, “The Republican Party and the Slave Power," in New Perspectives on Race and Slavery in America: Essays in Honor of Kenneth M. Stampp, ed. Robert H. Abzug and Stephen E. Maizlish (Lexington: University of Kentucky Press, 1986), 51-78; Gienapp, "The Crisis of American Democracy: The Political System and the Coming of the Civil War," in Why the Civil War Came, ed. Gabor S. Boritt (New York: Oxford University Press, 1996), 79-124; Michael F. Holt, The Political Crisis of the 1850s (New York: John Wiley \& Sons, 1978), vii-viii, 151-52, 180-217; Holt, "Making and Mobilizing the Republican Party, 1854-1860," 29-59; Kenneth Stampp, The Imperiled Union: Essays on the Background of the Civil War (New York: Oxford University Press, 1980), 122. 
Adopting that doctrine, Republicans insisted that Congress possessed the power and the duty to exclude slavery from the territories. Consequently, they pledged to establish freedom's supremacy in the federal government and to put slavery in the course of ultimate extinction. This was radical antislavery doctrine, inspired by the idea of equality, justified by antislavery legal theory, and animated by a desire to destroy slavery. ${ }^{4}$ Yet, as Lincoln's speeches demonstrate especially well, the Republicans cloaked this doctrine in conservative garb. The case for antislavery politics rested on the Republicans' promise to preserve rather than to destroy the nation. In large measure, Lincoln developed these ideas in rhetorical dialogue with Illinois Senator Stephen A. Douglas from 1854 to 1860 . Not coincidentally, Lincoln's fusion of the radical idea of equality with the conservative idea of national preservation helped him to distinguish Republican from northern Democratic politics, secure the Republican nomination for president, and attract enough swing voters in the 1860 election to complete the Republican revolution. Lincoln's election marked the triumph of the Republicans' conservative crusade for radical reform. ${ }^{5}$

As a prominent Illinois Whig, Abraham Lincoln articulated the core ideas of an antislavery nationalism in his anti-Nebraska speeches in

4. By claiming that Republicans endorsed "radical antislavery doctrine," I do not mean to imply that all Republicans shared the beliefs of political abolitionists. I do mean to highlight, however, the seismic political shift that occurred between 1854 and 1860 when the Republican Party came to power in the North by proclaiming doctrines that previously had been avowed by a relatively small minority of antislavery activists. This political shift meant that all Republicans, regardless of their radicalism or conservatism within the party, effectively endorsed a radical political creed. In this vein, it is worth observing that the Constitutional Convention would have been an abject failure had the Republicans' antislavery convictions prevailed among northern delegates in 1787. This essay therefore dovetails with scholarship that emphasizes the continuity of antislavery politics from 1840 onwards, most notably Richard H. Sewell's, Ballots for Freedom: Antislavery Politics in the United States, 1837-1860 (New York: Oxford University Press, 1976), vii-ix, 343-65.

5. Although nationalism was a subject of study for early historians of the Civil War and has been studied sporadically since, only relatively recently has the influence of theorists such as Benedict Anderson led historians to begin intensively investigating its significance for antebellum and wartime northern politics. Thomas J. Pressly, Americans Interpret Their Civil War (1954; reprint, New York: Free Press, 1969), 196-226; David M. Potter, ed., The South and the Sectional Conflict (Baton Rouge: Louisiana State University Press, 1968), 34-83; Paul C. Nagel, This Sacred Trust: American Nationality, 1798-1898 (New York: Oxford University Press, 1971); Major Wilson, Space, Time, and Freedom: The Quest for Nationality and the Irrepressible Conflict, 1815-1861 (Westport, Conn.: Greenwood Press, 1974); Benedict Anderson, Imagined Communities: Reflections on the Origin and Spread of Nationalism, 2d ed. (New York: Verso, 1991); Peter J. Parish, The North and the Nation in the Era of the Civil War, ed. Adam I. P. Smith and Susan-Mary Grant (New 
1854. His speeches responded to passage of the Douglas-authored Kansas-Nebraska Act, which struck down the antislavery provisions of the Missouri Compromise and enabled settlers to legalize slavery in the territories of Kansas and Nebraska under the auspices of popular sovereignty. Considering popular sovereignty as Douglas defined it to be "despotism," Lincoln bitingly observed that Thomas Jefferson never conceived of "the liberty of making slaves of other people." Instead, Lincoln claimed that the founders had opposed slavery on principle and tolerated it only from necessity, placing them in opposi-

York: Fordham University Press, 2003), 57-70, 113-46; Donald Ratcliffe, "The State of the Union, 1776-1860," in The American Civil War: Explorations and Reconsiderations, ed. Susan-Mary Grant and Brian Holden Reid (Harlow, England: Pearson Education, 2000), 3-38; Susan-Mary Grant, North Over South: Northern Nationalism and American Identity in the Antebellum Era (Lawrence: University Press of Kansas, 2000); Parish, "Abraham Lincoln and American Nationhood," in Legacy of Disunion: The Enduring Significance of the American Civil War, ed. Susan-Mary Grant and Peter J. Parish (Baton Rouge: Louisiana State University Press, 2003), 116-33; Susan-Mary Grant, "'The Charter of Its Birthright': The Civil War and American Nationalism," in Legacy of Disunion, 188-206; Melinda Lawson, Patriot Fires: Forging a New American Nationalism in the Civil War North (Lawrence: University Press of Kansas, 2002); and Stewart Winger, Lincoln, Religion, and Romantic Cultural Politics (DeKalb: Northern Illinois University Press, 2003), 134-46, 199-208. Of this body of work, Grant's impressive fleshing out of ideas first broached by Parish deserves special comment. Grant traced the "evolution of northern attitudes toward the South" during the antebellum decades and contended that Republican Party ideology both flowed from and shaped "a process of national construction by which the American national idea became associated with the North in general and the Republican Party in particular." But what Grant labels "northern nationalism" was hardly benign; rather, "this essentially antisouthern ideology" effectively precluded a "rational response to the South" by the 1850s and thus helped precipitate the Civil War. Although much of Grant's innovative argument complements my own, I believe that the phrase "antislavery nationalism" better captures the Republican appeal. The Republicans did not insist that the nation had been dedicated to the North. Rather, they insisted that it had been dedicated to freedom, and they claimed with considerable justification that the South had renounced its devotion to freedom. Moreover, while antisouthernism did deeply influence their ideology, the Republicans' hostility to the South flowed from their critique of slavery, and not vice versa. This point is significant. Had the Republicans been primarily antisouthern rather than primarily antislavery, reincorporating the South into the nation after the Civil War would have been far more difficult. However, one of the striking characteristics of Reconstruction was that most Republicans initially proved willing to readmit white southerners into the Union on generous terms despite the incredible carnage of the war. Postwar white southern resistance to slavery's destruction certainly caused Republicans to become more coercive, but even then the Republicans' zeal for reforming the South never matched their determination to destroy slavery, enabling white southerners to fairly rapidly "redeem" the South. For these reasons, the phrase "northern nationalism" miscasts the fundamental orientation of Republican nationalist sensibilities and encourages an overemphasis on the antisouthern aspects of their ideology at the expense of their antislavery convictions. Grant, North Over South, 9, 17, 62, 79, 116-17, 148-49, 150-52. 
tion to Douglas, whose popular sovereignty policies treated slavery as a "moral right." By contending that the founders had opposed slavery, Lincoln took the same ground as Illinois' leading anti-Nebraska Democrat, Lyman Trumbull, and Illinois' leading political abolitionist, Ichabod Codding, thus illustrating an area of ideological accord that would later help to unify the disparate anti-Nebraska factions into the Republican Party. But Lincoln drew on the Declaration of Independence to condemn the Kansas-Nebraska Act far more than most anti-Nebraskites. He considered the revolutionaries' document to be the touchstone of human liberty because it rested on the proposition of human equality, which justified a government based on consent rather than force. By contrast, the presumption of human inequality justified the despotic subordination of people deemed inferior, as southern slavery demonstrated. Therefore Lincoln considered the founders' legacy to be the best antidote to Douglas's popular sovereignty. "If the negro is a man," he argued, "then my ancient faith teaches me that 'all men are created equal;' and that there can be no moral right in connection with one man's making a slave of another." To Lincoln, this moral idea justified American government and gave meaning to American nationalism. Consequently, he urged all Americans to "repurify" the nation's ideals by implementing the antislavery extension policies that harmonized with the Declaration of Independence. In doing so, Americans would "not only have saved the Union," but have made it "forever worthy of the saving." This was a position that Lincoln considered "no less than National" in $1854 .{ }^{6}$

Lincoln consequently advocated antislavery policies in 1854 that sought to prevent slavery's expansion. His policies virtually matched later Republican Party doctrine, indicating the continuity in his ideology and policy from 1854 to 1860 . Unlike conservative anti-Nebraskites, he did not seek merely to reinstitute the Missouri Compromise. The anti-Nebraska resolutions he wrote in preparation for the 1855 session of the General Assembly urged Illinois' congressmen to oppose any attempt to revive the African slave trade, to resist the division of California into one slave and one free state, to refuse the admission of any slave state from Kansas or Nebraska Territories, and to "prevent domestic slavery [from] ever being established in any country, or place,

6. Collected Works, 2:240-83 (quotes, 266, 250, 276, 266, 276, 248); Quincy Weekly Whig, October 23 and 30, 1854; Ichabod Codding, Codding's Reply to Douglas: Substantially Codding's Speech in Reply to Douglas at Joliet and Geneva, in the Fall of '54, on the KansasNebraska Bill, and Slavery Extension, September 1854 (n.p.), Abraham Lincoln Presidential Library; Don E. Fehrenbacher, Prelude to Greatness: Lincoln in the 1850's (Stanford, Calif.: Stanford University Press, 1962), 23-24. 
where it does not now legally exist." These policies indicated Lincoln's determination to prevent slavery's perpetuity, and on this point he would never waver. Indeed, his memorable 1858 vow in the House Divided speech to place slavery in the "course of ultimate extinction" merely restated his 1854 sentiment that slavery's expansion must be opposed because it tended "to the perpetuation of the institution." He reminded Illinoisans in 1854, as he would later, that they had profound moral obligations to oppose slavery's expansion and no "legal" obligations to permit it. Therefore he proposed to resuscitate the policy of the founders, who had "hemmed" slavery into the "narrowest limits of necessity" and had expected its abolition "at the end of a given time." Clearly, Lincoln's antislavery extension policies did not merely spring from a desire to resuscitate a broken compact but from his determination to combat the Nebraska principle. He knew that the Nebraskites sought above all "to establish a principle, for FUTURE USE," which he warned would result in the "planting of slavery" wherever "local and unorganized opposition can not prevent it." Lincoln rebelled at such an insidious method of perpetuating a moral wrong. His moral conviction, and the antislavery extension policies engendered by it, characterized his politics from 1854 until the Civil War. ${ }^{7}$

In 1855 Lincoln's convictions enabled him to begin charting a course from Whiggery to Republicanism. Like many other politicians during this chaotic period, Lincoln treaded cautiously. In 1854, for instance, he had refused to fuse with, or join, men who sought to create an antislavery Republican Party in Illinois. He feared to act rashly in an uncertain political climate, particularly in concert with men who had a radical antislavery reputation. Nevertheless, opposition to the principle of Nebraskism led him towards an accord with the so-called fusionists. He wrote to the prominent Illinois abolitionist Owen Lovejoy in August 1855 that not "even you are more anxious to prevent the extension of slavery than I." To be sure, he urged Lovejoy to await the demise of the nativist Know-Nothing movement, which had mush-

7. Collected Works, 2:300-01 (quotes), 461 (quote), 263 (quote), 264 (quote), 274 (quotes), 273 (quotes). Although his anti-Nebraska resolutions are vague on this point, Lincoln probably would have sanctioned slavery's expansion into the southwestern territories that the Compromise of 1850 had organized under popular sovereignty. He indicated no desire in 1854 or thereafter to violate existing sectional compromises, and he did not believe that the admission of one more slave state would materially affect slavery's perpetuity. He mostly desired to establish a national policy that would henceforth preclude territorial slavery, believing that such a policy would eventually produce slavery's abolition. This attitude was especially evident during the secession crisis when he indicated his willingness to admit New Mexico as a slave state "if further extension were hedged against." Collected Works, 4:183. 
roomed in northern states from 1854 to 1855 , before promoting another convention to fuse Illinois' antislavery men into one party. He feared that "an open push by us now" to recruit Know-Nothings "may offend them, and tend to prevent our ever getting them." This caution was politically astute given the suspicions and enmities that divided the various antislavery groups in Illinois, not least of which was between the nativists and antislavery German immigrants. Nevertheless, Lincoln's own course was set. He told Lovejoy that he intended to "stand with any body who stands right," and he predicted that the fusion movement would rapidly congeal once the Know-Nothing movement disintegrated. Lincoln himself had nothing but contempt for nativism. He considered it an odious assault on human equality, similar in principle to Democratic racial dogma. Indeed, the nativists' hypocritical interpretation of the Declaration of Independence caused him to lament the nation's rapid "progress in degeneracy" and steeled his commitment to the principle of equality. ${ }^{8}$

Events that year in Kansas exacerbated Lincoln's growing concern for the nation's future and intensified his antislavery politics. He interpreted the violence of Kansas's proslavery party against antislavery settlers, and southerners' undisguised approval, as evidence that slaveholders had rejected the idea of universal liberty and intended to perpetuate slavery. This was a sobering thought. Unlike some northern Whigs, who stressed the emancipatory tendencies of a free labor political economy, Lincoln considered the individual conscience to be the engine of emancipation. Thus the South's apparently implacable opposition to "voluntary emancipation" led him to wonder whether the nation could remain united, forever, half slave and half free. Nevertheless, with characteristic resolve, he stuck to his antislavery convictions, played a leading role in Illinois' 1856 fusion movement, and received ample reward at the 1856 Republican state convention, where two hundred and seventy cheering delegates-including formerly antagonistic Whigs, Democrats, abolitionists, nativists, and Germans-voted for a party platform that vowed to return the government "to the principles and practices" of the Revolution by prohibiting slavery's spread "into territories heretofore free." Illinois Republicans had set aside their differences and fused harmoniously in order to combat the idea of a proslavery nation. ${ }^{9}$

8. Ibid., 2:316-17 (quotes), 323 (quote).

9. Ibid., 2:320-23, 318 (quote), 341; Paul Selby, “The Editorial Convention, February 22, 1856," McLean County Historical Society Transactions 3 (1900): 30-43; Ezra M. Prince, ed., "Official Record of Convention," McLean County Historical Society Transactions 3 (1900): 160-61 (quotes). 
In the 1856 campaign, Lincoln developed his antislavery conception of American nationalism by celebrating the superiority of free society. In 1854 he had briefly mentioned his desire to preserve the territories for "free white people," but in 1856 he tied the interests of free labor more explicitly to the ideals of free society. He attributed the nation's extraordinary "prosperity" to the "cause" that "every man can make himself," and he contended that "to give up that one thing, would be to give up all future prosperity." But Lincoln really referred to northern prosperity. His comparison of the northern and southern social systems led him to conclude that northerners had "an interest" in maintaining "the principles of the Government," and "without this interest" the government "is worth nothing." He reported to his northern audiences that southern newspapers, such as the Richmond Enquirer, claimed that "their slaves are far better off than Northern freemen." Lincoln ridiculed this idea because no fixed class of labor existed in the North. "The man who labored for another last year," he declared, "this year labors for himself, and next year he will hire others to labor for him." Lincoln therefore disdained any moral comparison between free and slave labor, or between free and slave society; in his estimation, no credible basis existed for the southern defense of slavery on "principle." Consequently, he urged northerners to keep "the Territories free for the settlement of free laborers" by defeating southern attempts to make slavery "a ruling element in our government." Lincoln had begun to conflate northern society and American nationalism. ${ }^{10}$

The 1856 elections gave Lincoln and the Illinois Republicans encouragement for the future. Democrat presidential candidate James Buchanan carried Illinois, but primarily because Millard Fillmore, the candidate for the nativist American Party, attracted former Whig and Know-Nothing voters whose fear of disunion discouraged them from voting for Republican Party candidate John C. Frémont. Yet most Fillmore voters were not hostile to the Republicans. Two-thirds of them voted for Illinois' Republican gubernatorial candidate, who won the election as a consequence. This victory energized the Illinois Republicans because it indicated that most nativists had antislavery tendencies and might well vote for a Republican presidential candidate who appeared sufficiently conservative. As Lincoln observed in December, Frémont and Fillmore voters in the North had a four hundred thousand-vote majority over Buchanan men. Therefore, if all northerners who were resolved "that free society is not, and shall not 
be, a failure," let "bygones be bygones," then northerners could "reinaugurate" the country's "central idea" of "the equality of men."11

To win next time, Illinois Republicans and the national party faced an identical challenge. Illinois Republicans needed to recruit additional voters in central and southern Illinois-the conservative regions of the state- just as the national party needed to acquire additional electoral votes in Pennsylvania, New Jersey, Indiana, and Illinois-the conservative regions of the North. Fillmore Whigs thus loomed large not only in Illinois but in the North generally. Since the Republicans needed to carry virtually every northern state to win the presidency in 1860 , they needed to defuse the Fillmore Whigs's fear of radicalism. This was not an easy task. Probably all Fillmore Whigs sympathized with Douglas's aversion to sectional conflict, and those with southern ties likely had more tolerance for slavery than did most other northerners. Converting their antislavery sentiment into antislavery politics thus required Republicans to denounce Douglas as much as the South. They needed to show that Douglas, the northern Democracy, and the principle of popular sovereignty posed as grave a danger to free society as did proslavery southerners. During the next four years, no Republican in the nation would do that more effectively than Abraham Lincoln.

Douglas's response to the Supreme Court's March 1857 Dred Scott decision created a tremendous opportunity for Lincoln to step to the fore. Scott was a slave who had sued for his freedom based on his earlier residence in both a free state and a free territory. In a complex decision written by Chief Justice Roger Taney, the court decided that blacks were not citizens of the United States and that congressional prohibitions on territorial slavery were unconstitutional; hence, Scott was not freed. In a June 1857 speech Douglas validated the Supreme Court's denial of citizenship rights to blacks and deliberately aligned northern Democratic ideology with a growing southern consensus on black rights. The country's early history "clearly shows," he claimed, that the founders regarded blacks "as an inferior race, who, in all ages, and in every part of the globe, and under the most favorable circumstances, had shown themselves incapable of self government, and consequently [were] under the protection of those who were capable of providing for and protecting them in the exercise of all the rights

11. Gienapp, Origins of the Republican Party, 417-18, 527, 531, 537; Collected Works, 2:385. Other useful data on the 1856 Illinois elections can be found in Stephen L. Hansen, The Making of the Third Party System: Voters and Parties in Illinois, 1850-1876 (Ann Arbor, Mich.: UMI Research Press, 1978), 70, 99, 109-10; Ray M. Shortridge, "Voting for Minor Parties in the Antebellum Midwest," Indiana Magazine of History 74 (June 1978): 131-33; and Shortridge, "The Voter Realignment in the Midwest During the 1850s," American Politics Quarterly 4 (April 1976): 204-12. 
they were capable of enjoying, consistent with the good and safety of society." This line of reasoning was congenial to Douglas partly because he agreed with Taney, whose opinion in large measure rested on an analysis of blacks' low status in the founding era, partly because he wished to find common ground with the South, and partly because, as Lincoln observed, he desired to "fasten the odium" of black equality on the Republicans. Thus Douglas endorsed Taney's contention that the Declaration of Independence excluded black people and correspondingly took issue with Republican racial doctrine. "If the negro is the equal of the white man," asked Douglas, how could the Republicans "reduce him to a condition of inequality, by denying to him the privilege of voting, holding office, [and] marrying the woman of his choice"? Douglas answered that they would not; rather, "as soon as they get the power," Republicans would enable blacks to "enjoy all the rights and privileges of citizenship on an equal footing with white men." Knowing that Lincoln considered human equality to be the nation's "central idea," from which subordinate ideas "radiate," Douglas likely anticipated Lincoln giving battle on the critical racial issue. If so, northern Democrats would profit dramatically from white racism in negrophobic Illinois. ${ }^{12}$

Douglas's expectations were not misplaced, but his racial gambit also enabled Lincoln to collapse distinctions between Douglas and the South. In an impassioned protest several weeks later, Lincoln challenged Douglas's interpretation of the Declaration of Independence. Lincoln maintained that the founders sought to establish "a standard maxim for free society, which should be familiar to all, and revered by all," thereby "spreading and deepening its influence, and augmenting the happiness and value of life to all people of all colors everywhere." Lincoln conceded that equal rights might never be "perfectly attained," but he insisted that the founders had declared "the right, so that the enforcement of it might follow as fast as circumstances should permit." Consequently, he deplored the Democrats' refusal to acknowledge blacks' inalienable rights and the Democrats' determination to roll back the few political privileges blacks possessed. To Lincoln, the Taney and Douglas racial doctrine culminated a retreat from the idea of equality since the Revolution and provided an intellectual and legal capstone to the nation's increasingly discriminatory

12. Don E. Fehrenbacher, The Dred Scott Case: Its Significance in American Law and Politics (New York: Oxford University Press, 1978), 323-24; Kansas, Utah, and the Dred Scott Decision: Remarks of the Hon. S. A. Douglas, delivered in the State House at Springfield, June 12, 1857 (n.p.), Abraham Lincoln Presidential Library, 5 (quote), 4 (quotes); Collected Works, 2:405 (quote), 385 (quotes). 
racial practices. By contrast, Lincoln discerned progressive possibilities in Republican racial doctrine and antislavery policy. "The Republicans inculcate, with whatever of ability they have, that the negro is a man; that his bondage is cruelly wrong, and that the field of his oppression ought not to be enlarged," argued Lincoln, but the "Democrats deny his manhood; deny, or dwarf to insignificance, the wrong of his bondage; so far as possible, crush all sympathy for him, and cultivate and excite hatred and disgust against him; compliment themselves as Union-savers for doing so; and call the indefinite outspreading of his bondage 'a sacred right of self-government." ${ }^{\prime \prime}$ Thus Lincoln identified the principles and objectives shared by Douglas and the southern Democrats, and in so doing laid bare the points at issue between Republicans and northern Democrats. In his hands Republican antislavery doctrine was less anti-southern than antiDouglas, and this emphasis would characterize his politics until the 1860 presidential election. ${ }^{13}$

Douglas's subsequent opposition to Kansas's Lecompton Constitution drove Lincoln to intensify his proslavery characterization of the northern Democracy. The Lecompton Constitution was the product of Kansas's proslavery party, which had used grossly fraudulent and anti-democratic means to draft and ratify a proslavery state constitution in late 1857. Incensed by this mockery of popular sovereignty and refusing to countenance it, Douglas broke with southern Democrats and President Buchanan, aligning instead with Republicans in Congress to reject the constitution. His course put Lincoln's strategy at risk. Indeed, Lecompton's defeat burnished Douglas's free-soil credentials so dramatically that prominent eastern Republicans supported Douglas's reelection to the Senate in 1858. Indignantly spurning this idea, Illinois Republicans took the unprecedented step of nominating Lincoln for the Senate at their June 1858 state convention. Nevertheless, Lincoln recognized that Douglas's rebellion against Lecompton had obscured distinctions between Republicans and the northern Democracy. Confronted by this crisis, Lincoln returned to fundamentals. The Republicans "think slavery is wrong" and "ought to be prohibited" from expansion, he reminded the party faithful, while Douglas "cares not" whether slavery in Kansas is "voted down or voted up." Lincoln considered this a "radical difference of opinion," and consequently he believed that the Republicans could not adopt Douglas's position without destroying the party. ${ }^{14}$

Lincoln inaugurated the senatorial campaign with a dramatic attempt

13. Collected Works, 2:406 (quotes), 318, 404 (quote), 409 (quotes).

14. Fehrenbacher, Prelude to Greatness, 48-69; Collected Works, 2:449 (quotes). 
to distinguish himself from Douglas. In his House Divided speech, delivered to the Republican state convention on June 16, he advanced his famous charge that Douglas, Pierce, Buchanan, and Taney had conspired to nationalize slavery. By his estimate, the Kansas-Nebraska Act and the Dred Scott decision were bookends to the nefarious scheme, although he anticipated a subsequent Supreme Court decision striking down antislavery laws in the northern states. This aspect of Lincoln's argument rested on a careful analysis of the Dred Scott decision, which had in fact established a legal basis for the Supreme Court subsequently to invalidate state as well as territorial prohibitions on slavery. Yet Lincoln's central argument rested on the biblical metaphor that a "house divided against itself cannot stand." Reasoning from this proposition, Lincoln argued that either Republicans would place slavery in the "course of ultimate extinction" or Democrats would "push it forward, till it shall become alike lawful in all the States." Lincoln's polarization of the slavery question eradicated any middle ground between slavery and freedom, while the conspiracy charge allied Douglas with proslavery expansionists. Lincoln could not have drawn the contrast between himself and Douglas any more sharply. ${ }^{15}$

Yet the House Divided speech in some respects overshot its mark. Although it did differentiate him from Douglas, it also channeled him away from his most effective arguments for the first three and a half months of the campaign. Partly this reflected the political skill of Douglas, who responded to the seeming extremism of the House Divided doctrine by calling Lincoln an abolitionist and disunionist. This put Lincoln on the defensive, and his worried advisors urged him to attack Douglas by delivering "the deadliest thrusts." Concurring with that advice, Lincoln frequently repeated his conspiracy charge, which seemed the best way of eroding Douglas's free-soil reputation, but for which he had little evidence. Nevertheless, Lincoln groped towards a more effective argument over the course of the campaign. In October he finally grasped how to best distinguish Douglas's politics from the principles and policies of the Republican Party. ${ }^{16}$

In the last three debates, Lincoln reemphasized the moral appeal he had first articulated in 1854 . He repeatedly argued that the Repub-

15. Fehrenbacher, Prelude to Greatness, 70-95; Collected Works, 2:461-62 (quotes).

16. Fehrenbacher, Prelude to Greatness, 123 (quote); Collected Works, 2:521, 522, 525-26, 538-41, 548-53; 3:20-29, 38, 45-49, 73-76, 146-58, 183-86; Richard J. Carwardine, Lincoln (Harlow: Pearson Education, 2003), 77, 89 n. 51. For a dramatically different assessment of the effectiveness of the House Divided speech, see Harry V. Jaffa, A New Birth of Freedom: Abraham Lincoln and the Coming of the Civil War (New York: Rowman \& Littlefield, 2000), 311-21. 
licans, in contrast to Douglas, considered slavery "a moral, a social and a political wrong." He judged that this was the "real difference" between the parties, from which sprung the Republicans' determination to treat slavery as a wrong by making "provision that it shall grow no larger." As always, Lincoln emphasized the antislavery character of the Declaration of Independence, which enabled him to root his moral argument in nationalism rather than theology. Indeed, he used the Declaration as a bridge to the founding fathers, claiming that they had shared his moral convictions and consequently had placed slavery in "the course of ultimate extinction" by abolishing the slave trade and prohibiting slavery's expansion. He called this "the peaceful way" of cutting slavery from the body politic, and therefore he maintained that Republican antislavery extension policy "proposed nothing more than a return to the policy of the fathers." These were not entirely new ideas with Lincoln, but he had begun to assemble them into a cohesive, powerful, and partisan antislavery nationalism that Douglas totally rejected. ${ }^{17}$

Indeed, Lincoln's moral argument enabled him more effectively to bind Douglas to the idea of slavery's perpetuity in America. Confronted by Lincoln's invocation of the founders' antislavery intentions, Douglas rebutted that the founders had "made" the nation half slave and half free. Unlike Lincoln, he perceived no reason that the nation need become all one thing or all the other. Instead, he maintained that the Republic could "exist forever divided into free and slave States" if Americans applied the principle of popular sovereignty to the nation's territories. Gratefully fastening onto Douglas's statement, Lincoln contended that we "are getting a little nearer the true issue of this controversy." Lincoln castigated Douglas's expansionism on the same grounds. At Freeport, Douglas had declared that the nation should acquire more territory as necessary, without regard to slavery's expansion. Discerning the seeds of slavery's perpetuation in this policy, Lincoln contended that unbridled expansionism rested on the doctrine that slavery "is not wrong," deliberately facilitated slavery's expansion, and incorporated slavery into American nationalism..$^{18}$

Lincoln's distillation of the moral argument also enabled him to utilize his conspiracy charges effectively as an adjunct argument. In the House Divided speech, he had argued that Douglas's "care not" policy constituted a part of the conspiracy to nationalize slavery, serving to "educate and mould" northern public opinion "to not care whether slav-

17. Collected Works, 3:254 (quote), 314, 257 (quote), 313 (quotes), 220, 234, 280-81, 300-5, 276 (quote), 308 (quote).

18. Ibid., 3:274 (quotes), 29, 276 (quote), 235, 256 (quote). 
ery is voted down or voted up." This was the most persuasive aspect of the conspiracy charge because it did in fact describe the consequences if not the intentions of Douglas's ideas. Lincoln strengthened this argument in the last three debates by pairing it with a legal syllogism that demonstrated the likelihood of slavery's nationalization. Lincoln observed that nothing in the "laws of any State" could destroy a right "expressly affirmed" in the Constitution; the Dred Scott decision "expressly affirmed" the "right of property in a slave"; therefore, nothing in the "laws of any State" could "destroy the right of property in a slave." By deemphasizing the alleged political conspiracy, this argument narrowed Douglas's culpability for slavery's nationalization, yet still permitted Lincoln to call Douglas the man most culpable for "preparing the public mind" to take the next Supreme Court decision "when it comes." Lincoln did not charge that Douglas considered slavery to be right; but he did claim that moral indifference would cause Douglas to endorse southern jurists who thought it right. Like southerners, Douglas would willingly put slavery on the "cotton gin basis" of self-interest, which Lincoln believed would lead to slavery's nationalization rather than to its ultimate extinction. ${ }^{19}$

Lincoln's appeals proved only a partial success. He failed to poach Douglas's supporters or to decisively win the Fillmore vote, resulting in a tightly contested defeat. However, the contest was so close that the Democrats lost Illinois' statewide offices because a vengeful President Buchanan-embittered by Douglas's opposition to the Lecompton Constitution-had spurred pro-Lecompton candidates to challenge the Democratic nominees of the state party Douglas controlled. The Lecompton Democrats won few votes, but enough to shift the balance of power. As in 1856, Illinoisans had not decisively supported one or another of the parties, and therefore the state would be a crucial battleground in the 1860 campaign. $^{20}$

Cognizant of these facts, Lincoln developed a political strategy to win the state in 1860. His planning centered on the defeat of Douglas, who was the central obstacle to the Republicans' triumph. Presciently, Lincoln predicted that southern demands for a territorial slave code would soon create another "blow up" in the Democracy,

19. Ibid., 2:464 (quote), 465 (quotes), 500-1; 3:230-34 (quotes, 231, 233), 250-51, 277-78, 312-16 (quotes, 316).

20. David Herbert Donald, Lincoln (New York: Simon \& Schuster, 1995), 227-29; Fehrenbacher, Prelude to Greatness, 112-20; Bruce Collins, "The Lincoln-Douglas Contest of 1858 and Illinois' Electorate," Journal of American Studies 20 (December 1986): 399-420; Hansen, Making of the Third Party System, 114-15. The Lecompton Democrats did not alter the outcome of the Senate race because the Illinois legislature rather than the people at-large elected senators. 
forcing Douglas to break with southern Democrats. In that case, Lincoln observed, "the struggle in the whole North will be, as it was in Illinois last summer and fall, whether the Republican party can maintain it's [sic] identity, or be broken up to form the tail of Douglas' new kite." Lincoln realized that such a contest might not redound to the Republicans' advantage. Conservative Whigs in contested states like Illinois would likely hold the balance of power in 1860, and an independent Douglas would make a strong bid for just those voters. Faced with this possibility, Lincoln knew that he had to redouble his efforts to persuade conservative Whigs to adopt the party's radical aims, while convincing the party's radical arm to unify harmoniously with the conservative recruits. ${ }^{21}$

For these reasons, Lincoln widely propagated an antislavery nationalism in the sixteen months after his defeat. He believed that the doctrine, battle-tested in Illinois, could unify the party's not-quite-cohesive elements, and he used his newly acquired national reputation to disseminate his ideas widely. He soon received requests to speak in other states, and in Illinois he exercised unchallenged leadership of the Republican Party. His efforts to unify the party initially concentrated in Illinois. He urged Chicago Republicans not to demand radical policy from downstate Republicans, and meanwhile scolded central Illinois Republicans who censured the "ultra" antislavery men of the North. Lincoln soon branched out to national affairs. He urged Ohio Republicans to drop their opposition to the fugitive slave law, informed Massachusetts Republicans that nativism undermined liberty, instructed Kansas Republicans to steer clear of popular sovereignty, and encouraged a leading Indiana Republican to keep "explosive" issues out of the party's 1860 national platform. Disdaining the idea that every party member should agree "upon every minor point," Lincoln instead urged party members to rally around the "great principle" of slavery's wrong and the central object of "preventing the spread and nationalization of Slavery." He was beginning to put his distinctive stamp on Republican Party ideology.22

Lincoln refined his nationalist ideology in response to Douglas's September 1859 essay in Harper's Magazine. Seeking to justify the policy of popular sovereignty, Douglas contended that the founders had enshrined the principle of local self-government in the Constitution and early territorial law. From this basis, Douglas argued that Congress could confer-but not exercise-powers over a territory's

21. Collected Works, 3:340, 342 (quote), 345 (quote), 365-66.

22. Ibid., 3:389 (quote), 391 (quote), 366-70 (quotes, 366), 378-81 (quote, 379), 384, 386, 394-95, 432-35; Donald, Lincoln, 230-32. 
"domestic affairs," most notably slavery. Although Lincoln considered the essay a gross perversion of American history and a dangerous philosophical defense of slavery, it gave him another ideal opportunity to define Republican politics by combating Douglas. In a series of speeches given in Ohio, Indiana, and Wisconsin in September, and Kansas in December, Lincoln took issue with Douglas's historical argument. At Columbus, he developed ideas broached briefly in a speech at Carlinville a year earlier, claiming that the Republicans' "original and chief purpose" was the "eminently conservative" object of preventing slavery's nationalization. He explained that the Republicans promised "to restore this government to its original tone," desiring no more in relation to slavery "than that which the original framers of the government themselves expected." Despite his professed conservatism, these arguments were no more than a freshly minted version of his ultimate extinction doctrine. After all, he maintained that the founders had intended freedom's nationalization. He observed that the Constitution's authors had avoided the words "slave or slavery" because they expected slavery's extinction, and he argued that passage of the Northwest Ordinance evinced the founders' intention to slowly kill it. ${ }^{23}$

Lincoln built on this argument by fusing antislavery nationalism to the interests of free society. He pointed out that Indiana's settlers unsuccessfully petitioned the government at an early date to suspend the antislavery provision of the Northwest Ordinance, and he argued that Ohio, Indiana, and Illinois would all likely have become slave states had the Ordinance not warded off slaveholders. As proof, he observed that slavery now flourished on one side of the Ohio River but not on the other. The nation's history thus demonstrated that law, rather than climate, determined slavery's spread. Reasoning from this proposition, Lincoln invoked free labor arguments to demonstrate the need for antislavery law. Comparing the "mud-sill" theory of labor, in which laborers were fixed in their position for life, and free labor, in which laborers accumulated capital throughout their life, Lincoln contended that free labor was a "just and generous, and prosperous system, which opens the way for all — gives hope to all, and energy, and progress, and improvement of condition to all." To Lincoln, slavery deliberately destroyed the "inspiration of hope" required for "human exertion," while free labor encouraged men to innovate and

23. Harry Jaffa and Robert W. Johannsen, eds., In the Name of the People: Speeches and Writings of Lincoln and Douglas in the Ohio Campaign of 1859 (Columbus: The Ohio State University Press, 1959), 58-125 (quote, 65); Collected Works, 3:77, 404 (quotes), 412-17, 464-66 (quote, 466). 
excel. Given these considerations, he urged northerners to return to the ideals that served their interests. In his estimation, progress was "the order of things" only in "a society of equals." Never before had Lincoln so completely conflated northern interests and American nationalism. ${ }^{24}$

Lincoln brought antislavery nationalism to its zenith in his Cooper Union address of February 1860. Invited to talk in New York City, as he had earlier been invited to speak throughout the Northwest, Lincoln accepted with alacrity. The invitation marked his growing stature and provided him with an unparalleled opportunity to present his views to some of the nation's most powerful Republicans. He pondered the subject of his address in light of both John Brown's recent raid at Harper's Ferry, which had dramatically polarized the nation, and his growing chances for the party's presidential nomination. The first required him to defend the Republican Party from charges of incendiarism, and the second encouraged him to use words that calmed skittish northern Whigs. His characteristic cloaking of antislavery policy in a putatively conservative nationalism was perfectly suited to the occasion. His task was to indelibly associate the founders with antislavery values, showing that slavery contradicted the ideals of a nation that slaveholders did much to form. ${ }^{25}$

Lincoln's argument was a masterpiece of misdirection. He ostensibly argued for a conservative antislavery extension policy that comported with the will of the founders, yet in fact he issued a radical manifesto against slavery that denounced disunionism and importuned Republicans to resist it at any cost. Lincoln achieved this startling result with means as covertly radical as his ends. His tone resonated with reasonableness, and with a set of ingeniously misleading arguments he breathed a spirit of conservatism into the three portions of his speech, successively addressed to Douglas, southerners, and Republicans. His initial argument locked horns with the Harper's Magazine essay and conclusively demonstrated that a majority of the signers of the U.S. Constitution believed that Congress possessed the power to prohibit slavery in the nation's territories. This carefully researched contention was straightforward, but in a masterful sleight of hand Lincoln inferred from it that the founders intended to put slavery in the course of ultimate extinction, a conclusion that did not follow from the premises. After all, as Lincoln conceded in a different context in the speech, the power to prohibit territorial slavery did not imply the expediency of doing so. This was no small discrepancy

24. Collected Works, 3:437, 454-59, 466-69, 478 (quote), 479 (quote), 462 (quotes).

25. Donald, Lincoln, 237-41; Carwardine, Lincoln, 97. 
considering that Lincoln's idea of an antislavery nation rested upon his historical argument. ${ }^{26}$

The founders' thinking on slavery was considerably more complex than Lincoln acknowledged. While most founders professed antislavery ideals and hoped for slavery's end, their expectations of its death typically amounted to little more than a progressive faith in free labor political economy. Meanwhile, the Constitution they created was preeminently a practical document designed to establish a governance structure suitable for the diverse interests and extensive size of the infant United States. Determined to protect slavery in the new government, some southern delegates demanded concessions from northern delegates as the price of union. These southern delegates had no desire whatsoever to promote the ultimate extinction of slavery, and especially not through the auspices of the new federal government, whose potential power to destroy slavery greatly concerned them. Consequently, northern delegates hostile to slavery, such as Gouverneur Morris, ultimately had to sacrifice their antislavery convictions in order to create the Union. Meanwhile, some New England delegates proved quite willing to trade proslavery concessions for protections for commerce. In stark contrast to the Constitution's authors, the Republicans deliberately sought to annihilate slavery-and hence risked destruction of the Union-because they feared slavery's vitality and expected it to expand. Their assumptions and intentions therefore differed radically from those of the founders. Consequently, Lincoln's claim that Republican antislavery policy descended directly from the founders flowed from a distinctly selective reading of the nation's past. ${ }^{27}$

26. Harry V. Jaffa, Crisis of the House Divided: An Interpretation of the Issues in the Lincoln-Douglas Debates (1952; reprint, Chicago: University of Chicago Press, 1982), 310-29; George B. Forgie, Patricide in the House Divided: A Psychological Interpretation of Lincoln and His Age (New York: W. W. Norton, 1979), 124-42; David Zarefsky, Lincoln, Douglas, and Slavery: In the Crucible of Public Debate (Chicago: University of Chicago Press, 1990), 141-54, 163-65, 213-14; Harold Holzer, Lincoln at Cooper Union: The Speech That Made Abraham Lincoln President (New York: Simon \& Schuster, 2004), 128-29, 134-36, 144, 233; John A. Corry, Lincoln at Cooper Union: The Speech That Made Him President (Xlibris, 2003), 133; Collected Works, 3:522-50.

27. Notably, the founders had not done much to put slavery in the course of ultimate extinction. The southern founders refused to prohibit slavery's southwestern expansion, and they may well have opposed the antislavery provision of the Northwest Ordinance had they not presumed that slavery was ill suited for northern latitudes. For scholarship on slavery and the nation's founding, see Staughton Lynd, "The Abolitionist Critique of the United States Constitution," in The Antislavery Vanguard: New Essays on the Abolitionists, ed. Martin Duberman (Princeton, N.J.: Princeton University Press, 1965), 209-39; William W. Freehling, "The Founding Fathers and Slavery," American Historical Review 
Lincoln very likely flattened out the historical record deliberately. Admittedly, no historian can identify the intent of an historical actor with certainty. Perhaps Lincoln believed that every iota of the historical record justified his interpretation. However, his extensive preparation for the Cooper Union address combined with his logician's mind and masterful command of language strongly suggests that his conservative cloaking of antislavery policy was deliberate and shrewd. With finely honed lawyerly skill, he made the best case possible for his position..$^{28}$

Lincoln built on his ingenious argument by pinning the odium of radicalism on the South. This was a logical deduction from his premises. If Republicans contended for the "old policy" of the government,

77 (February 1972): 81-93; Don E. Fehrenbacher, "Slavery, the Framers, and the Living Constitution," in Slavery and Its Consequences: The Constitution, Equality, and Race, ed. Robert A. Goldwin and Art Kaufman (Washington, D.C.: American Enterprise Institute, 1988), 1-22; William M. Wiecek, "'The Blessings of Liberty': Slavery in the American Constitutional Order," in Slavery and Its Consequences, 23-44; Herbert J. Storing, "Slavery and the Moral Foundations of the American Republic," in Slavery and Its Consequences, 45-63; W. B. Allen, "A New Birth of Freedom: Fulfillment or Derailment?" in Slavery and Its Consequences, 64-92; Leonard L. Richards, The Slave Power: The Free North and Southern Domination, 1780-1860 (Baton Rouge: Louisiana State University Press, 2000), 28-51; and Don E. Fehrenbacher, The Slaveholding Republic: An Account of the United States Government's Relations to Slavery, completed and ed. Ward M. McAfee (New York: Oxford University Press, 2001), 15-47.

28. Lincoln so successfully promoted a moderate image that historians have not always recognized the radical character of the Cooper Union speech. For example, see Donald, Lincoln, 240, and Robert W. Johannsen, Lincoln, the South, and Slavery: The Political Dimension (Baton Rouge: Louisiana State University Press, 1991), 98-99. For an alternative perspective on Lincoln's intent at Cooper Union, see John Channing Briggs, Lincoln's Speeches Reconsidered (Baltimore, Md.: Johns Hopkins University Press, 2005), 237-56. For more general analyses of Lincoln's interpretation of slavery and the founding, see Phillip Shaw Paludan, "Hercules Unbound: Lincoln, Slavery, and the Intentions of the Framers," in The Constitution, Law, and American Life: Critical Aspects of the Nineteenth-Century Experience, ed. Donald G. Nieman (Athens: University of Georgia Press, 1992), 1-22; Philip S. Paludan, "Lincoln's Prewar Constitutional Vision," Journal of the Abraham Lincoln Association 15 (Summer 1994): 1-21; David Zarefsky, "'Public Sentiment Is Everything': Lincoln's View of Political Persuasion," Journal of the Abraham Lincoln Association 15 (Summer 1994): 31-37; Drew R. McCoy, "Lincoln and the Founding Fathers: A Reconsideration," Journal of the Abraham Lincoln Association 16 (Winter 1995): 1-13; Kenneth M. Stampp, "Lincoln's History," in "We Cannot Escape History": Lincoln and the Last Best Hope of Earth, ed. James M. McPherson (Urbana: University of Illinois Press, 1995), 17-32; Jaffa, A New Birth of Freedom, 285-303; Allen C. Guelzo, "Apple of Gold in a Picture of Silver: The Constitution and Liberty," in The Lincoln Enigma: The Changing Faces of American Icon, ed. Gabor Boritt (New York: Oxford University Press, 2001), 86-107; Joseph R. Fornieri, Abraham Lincoln's Political Faith (DeKalb: Northern Illinois University Press, 2003), 133-64; and Winger, Lincoln, Religion, and Romantic Cultural Politics, 49-50, 59-60, 134-46. 
as he maintained, then southerners "reject, and scout, and spit upon that old policy." By refusing to adopt antislavery extension politics, as had the founders, southerners branded themselves as unworthy heirs to the national patrimony. Consequently, Lincoln characterized their threats to destroy the union as a "great crime." They had neither legal nor moral right to take such action. Although Lincoln's argument against disunion had much to recommend it, he had again shifted the grounds of the debate. In effect, he combated charges of Republican radicalism by charging that crime upon the South. In truth, both southerners and Republicans bore responsibility for polarizing the slavery issue, but Lincoln insisted that "the greater prominence" of the slavery issue since the nation's founding stemmed solely from proslavery "innovation" on the "old times." By advancing this argument with a seemingly transcendent objectivity, Lincoln skillfully adapted his ideas to the scruples of conservative Whigs. ${ }^{29}$

This line of reasoning enabled Lincoln to claim that antislavery nationalism was eminently conservative. In the final segment of his speech, he urged Republicans to promote "peace" and "harmony" even "though much provoked," and to "yield" to southern demands if "we possibly can." This passage immediately followed his critique of disunion and seemingly testified to his conciliatory spirit. Yet his deft use of the moral argument soon indicated that he had issued the conciliatory sentiments in order to harden Republican antislavery resolve. Much as he had done with Douglas, he insisted that southerners thinking slavery right, "and our thinking it wrong, is the precise fact upon which depends the whole controversy." He conceded that if slavery was right, southerners could justifiably ask for its nationalization, but if it was wrong they could not demand its extension. Thus Republicans could not, after all, "yield" to the South, but instead must stand by their duty inflexibly and unflinchingly. Remarkably, Lincoln's conciliatory beginning culminated in a steely peroration in which he commanded Republicans to oppose slavery's extension "TO THE END," daring "TO DO OUR DUTY AS WE UNDERSTAND IT." Through Lincoln's exquisite manipulation, the moralism of a Codding was now the duty of a nation. ${ }^{30}$

Lincoln's exposition of Republican thought contributed decisively to his presidential nomination in Chicago. The Republicans' one vexing problem in 1860 was the absence of a suitable nominee. None of the party's leading lights precisely fit the bill. New York's William Seward and Ohio's Salmon P. Chase seemed too radical to win the critical states of Pennsylvania, Indiana, and Illinois; Pennsylvania's

29. Collected Works, 3:537 (quotes), 547 (quote), 538 (quotes).

30. Ibid., 3:547 (quotes), 550 (quotes). 
Simon Cameron had too many enemies in his own state and too few principles and scruples to inspire the confidence of men elsewhere; Missouri's Edward Bates had an overly strong nativist heritage and little antislavery pedigree; and age bowed down Supreme Court Justice John McLean, whose mainstream principles would otherwise have recommended him. The lack of a strong candidate highlighted the continuing divisions within Republican ranks. The national party, like the Illinois state party, needed to unify a discordant mix of radicals, moderates, conservatives, immigrants, and nativists in a manner appealing to voters in the crucial lower north states. Under the circumstances, as Lincoln's advisors quickly discovered in Chicago, the man most responsible for uniting Illinois' state party had perfect credentials for the presidential nomination. The antislavery nationalism he had fashioned to bring Illinoisans together proved ideally suited to the entire North. Indeed, his representatives at the convention-a northern Illinois Democrat, a German, and two conservative Whigs—suggested his unusual capacity to bridge ideological divides. Perhaps not surprisingly, the convention delegates refused "lightly to throw away," as Lincoln had once remarked of Douglas's wide-ranging appeal, this "power to perform wonders." The atypical characteristics of Illinois politics had produced a man uniquely suited for national leadership of the Republican Party. ${ }^{31}$

The 1860 election confirmed the wisdom of the delegates at the Republican convention. Lincoln won all of the electoral votes in every free state except New Jersey, demonstrating strength across the ideological spectrum. He edged out Douglas in Illinois by taking threefourths of the 1856 Fillmore vote, two-thirds of the German vote, and two-thirds of the newly eligible voters. In Pennsylvania, he attracted an astonishing 87 percent of the Fillmore men and virtually all of the newly eligible voters who cast a ballot. These patterns held, somewhat more moderately, for the North at large. According to William Gienapp, accessions from non-Catholic immigrants, young voters, and Know-Nothings largely explain the increase of the Republicans' vote from 1856 to 1860 . The Republicans' success in attracting the support of such disparate groups while holding on to their 1856 antislavery

31 Fehrenbacher, Prelude to Greatness, 143-59; Donald, Lincoln, 240-50; Foner, Free Soil, Free Labor, Free Men, 205-18; Carwardine, Lincoln, 90-109; Collected Works, 3:453. To be sure, convention delegates did not nominate Lincoln solely on ideological grounds. As other historians have noted, his residence in Illinois, his Whig antecedents, his support for a protective tariff, his support among Germans, and the effective lobbying of Illinois delegates at the convention did much to recommend him. But his ideology enabled him to transcend the particularistic aspects of his Whig heritage and Illinois residence, and to appeal to a broad constituency. 
constituency in no small part reflected Lincoln's appeal; and the tightness of the contest in the crucial lower north states indicates that the Republicans might well have lost their majority in the electoral college had they instead nominated New York's William Seward, Lincoln's chief rival at Chicago. The Republicans" "Rail Splitter" mythologizing was apt indeed. Lincoln was, after all, an ideal representative of free society. ${ }^{32}$

Yet Lincoln's devotion to free society was thoroughly nationalist. To Lincoln, universal liberty represented the nation's guiding principle; self-government represented its greatest achievement; free labor represented its prodigious strength; and northern society represented its true character. Imbued with these convictions, Lincoln considered slavery unjust, slave society antiprogressive, and proslavery politics antagonistic to the idea of liberty and the existence of free society. Consequently, his radical opposition to slavery took the cast of national preservation from the inception of the anti-Nebraska movement. Lincoln was not entirely unique in this regard. The Nebraska Act's wanton aggression on freedom clothed the antislavery movement in a preservationist mantle that it had never before enjoyed and would never later relinquish. Certainly the movement could not have taken shape as it did without such a shocking assault on the interests and prerogatives of freedom. ${ }^{33}$

32. Gienapp, “Who Voted for Lincoln," 67-68, 76-77, 80-82; John M. Rozett, "Racism and Republican Emergence in Illinois, 1848-1860: A Re-Evaluation of Republican Negrophobia," Civil War History 22 (June 1976): 113-14; Walter D. Kamphoefner, "St. Louis Germans and the Republican Party, 1848-1860," Mid-America: An Historical Review 57 (April 1975): 74-75, 87-88; James Bergquist, "People and Politics in Transition: The Illinois Germans, 1850-60," in Ethnic Voters and the Election of Lincoln, ed. Frederick C. Luebke (Lincoln: University of Nebraska Press, 1971), 215; Bergquist, "The Political Attitudes of the German Immigrant in Illinois, 1848-1860" (Ph.D. diss., Northwestern University, 1966), 317-21. For an argument that Illinois' Fillmore vote went to Douglas and the Constitutional Union Party candidate John Bell in 1860, see Hansen, Making of the Third Party System, 123-24. For a penetrating examination of how Lincoln's moral appeals attracted antislavery Protestant voters, one of the Republican Party's core constituencies, see Richard J. Carwardine, "Lincoln, Evangelical Religion, and American Political Culture in the Era of the Civil War," Journal of the Abraham Lincoln Association 18 (Winter 1997): 27-55 and Carwardine, Lincoln, 114-30.

33. For stimulating treatments of Lincoln's nationalism, see Jaffa, Crisis of the House Divided, 330-33; Mark E. Neely Jr., "Abraham Lincoln's Nationalism Reconsidered," Lincoln Herald 76 (Spring 1974): 12-28; Joseph R. Fornieri, "Abraham Lincoln and the Declaration of Independence: The Meaning of Equality," in Abraham Lincoln: Sources and Styles of Leadership, ed. Frank J. Williams, William D. Pederson, and Vincent J. Marsala (Westport, Conn.: Greenwood Press, 1994), 45-69; Fornieri, Abraham Lincoln's Political Faith; Otto H. Olsen, "Abraham Lincoln as Revolutionary," Civil War History 24 (September 1978): 213-24; and Winger, Lincoln, Religion, and Romantic Cultural Politics, 134-46, 199-208. 
Nevertheless, Lincoln united antislavery radicalism with national preservation more powerfully than perhaps any other Republican. This stemmed from his unusual antislavery perspective. Although his critique of slavery was fundamentally moral, and although he frequently used biblical metaphors and language, he did not primarily think of slavery as a sin against God. Nor did he centrally concern himself with the naked struggle over sectional political power or the promotion of free labor political economy, as did many other Republicans. Instead, he perceived slavery as a moral challenge to American citizens. After all, slavery had been nurtured in American soil, propagated by American slaveholders, and protected, to an extent, by the American constitution. This nationalist outlook placed him nearer to the political abolitionists than to any other group of Republicans. But many of them sought to make the national constitution into an antislavery instrument, hoping to turn the law and the courts in favor of freedom. Lincoln, by contrast, rested his hopes on the moral sentiments of the people and sought to turn the people in favor of freedom. Therefore, he told northerners that the Declaration of Independence articulated the moral foundations of free society and the moral obligations of American government, and he urged northerners to do their duty by halting slavery's advance and preserving freedom. The precepts of an antislavery nation, and the progress of free society, required no less. ${ }^{34}$

As Lincoln comprehended, advocacy of an antislavery nationalism sharply distinguished Republicans from northern Democrats. Neither Stephen A. Douglas nor any other leading northern Democrat could sanction an ideology that condemned slavery as un-American without precipitating a southern Democratic rebellion that would destroy the Democratic Party and probably the Union. For that reason, Douglas adamantly contested Lincoln's reading of American history, claiming instead that the founders had made the country half-slave and halffree and pillorying Lincoln as a radical whose doctrines threatened to rend the Union. In doing so, Douglas sought to attract the same northern conservative swing voters pursued by Lincoln and the Re-

34. Lincoln's antislavery attitudes, of course, did not represent the thinking of every Republican. Nor, conversely, could he claim exclusive credit for promoting the idea of a nation dedicated to liberty. As Eric Foner has argued, Salmon P. Chase was primarily responsible for developing "an interpretation of American history which convinced thousands of northerners that anti-slavery was the intended policy of the founders of the nation." Nevertheless, Lincoln played a key role in shaping the antislavery appeal so that it appealed to a wide cross section of northern voters by the late 1850s, and this was a critical accomplishment. Foner, Free Soil, Free Labor, Free Men, 73. I thank Tom Schwartz for sharing his thoughts on Lincoln's antislavery attitudes. 
publicans. A variety of reasons explain why he was unable to win their loyalty: their abiding bitterness at his role in driving the inflammatory Kansas-Nebraska Act through Congress in 1854; their deep hostility to the Irish Catholic voters who so strongly supported him; southern delegates' demand for congressional protection of territorial slavery at the 1860 Democratic National Convention in Charleston, which tore the Democratic Party asunder and eroded Douglas's claim to represent the interests of both northerners and southerners; and northerners' increasing hostility to perceived southern high-handedness. Indeed, the violence of proslavery settlers in Kansas Territory, South Carolina Representative Preston S. Brooks's vicious beating of Massachusetts Senator Charles Sumner, Kansas's fraudulent Lecompton Constitution, and the destruction of the Democratic Party at Charleston all pushed swing voters towards the Republicans.

Yet the precepts of an antislavery nationalism played probably the most critical role in driving the votes of conservative northerners to Lincoln rather than Douglas. After all, the founding generation had articulated universal claims for human liberty in order to justify the Americans' revolutionary struggle for freedom, and therefore the idea of a nation dedicated to liberty was surely compelling to any northerner who considered freedom superior to slavery. Moreover, the logical deduction from this premise was that the interests of freedom should continue to predominate in the country, slavery's continued existence notwithstanding. Hence the Republicans' fusion of the past, present, and future in a nationalist ideology that justified antislavery politics philosophically and instrumentally had tremendously persuasive power. Although radical in practice, it seemed thoroughly justified, deeply moral, and eminently reasonable, and moreover it unhesitatingly promised to favor the interests of the North.

Additionally, the partisan convictions of both conservative Whigs and former Know-Nothings predisposed them towards endorsing an antislavery nationalism. A large majority of northern Whigs and Know-Nothings opposed slavery, even if unionist or nativist convictions blunted, and in some cases precluded, their participation in antislavery politics. Meanwhile, northern Know-Nothings had developed a strong nationalist creed, promoting national regeneration through nativist reforms and antislavery policy. Such attitudes made them susceptible to Lincoln's antislavery nationalism, which touched directly on one of their central concerns despite his private detestation of nativism. Finally, Lincoln's seeming moderation surely swayed some Whigs who had voted for Millard Fillmore in 1856; after all, the American Party had promoted sectional conciliation that year 
as avidly as they had nativism. By thus attracting a crucial cadre of conservative recruits, the Republicans' nationalist appeals helped bring their party to power in $1860 . .^{35}$

Yet antislavery nationalism also helped propel the nation to war. Republicans had gambled by organizing a party on antislavery principles. The idea of a nation dedicated to freedom, and pledged against slavery, challenged the South as sharply as Douglas's Kansas-Nebraska Act had challenged the North. After all, southerners considered slavery to be a positive good and imagined a proslavery past. They remembered southern founders who secured constitutional protections for slavery, facilitated slavery's expansion, and censured antislavery agitation. Consequently, southerners clung fiercely to their political and economic interests in slavery and pronounced slavery to be an exemplary method of social organization. They even deprecated free labor political economy and claimed that northern exactions, such as the tariff, plundered southern wealth. Given their growing conception of a proslavery nation, the election of a president who claimed that the founders' mandate required slavery's ultimate extinction provoked them to secede. ${ }^{36}$ Here the dialectic of irreconcilable antislavery and pro-

35. For scholarship on nativism and the Republican Party, see Foner, Free Soil, Free Labor, Free Men, 226-60; William E. Gienapp, "Nativism and the Creation of a Republican Majority in the North before the Civil War," Journal of American History 72 (December 1985): 529-59; Joel H. Silbey, The Partisan Imperative: The Dynamics of American Politics before the Civil War (New York: Oxford University Press, 1985), 127-65; Tyler Anbinder, Nativism and Slavery: The Northern Know Nothings and the Politics of the 1850s (New York: Oxford University Press, 1992); Bruce Levine, "Conservatism, Nativism, and Slavery: Thomas R. Whitney and the Origins of the Know-Nothing Party," Journal of American History 88 (September 2001): 455-88; and Mark Voss-Hubbard, Beyond Party: Cultures of Antipartisanship in Northern Politics before the Civil War (Baltimore, Md.: Johns Hopkins University Press, 2002), 178-216.

36. Although the subject lies beyond the purview of this essay, the process by which antebellum memories of the nation's founding fueled the sectional crisis deserves more study by historians than it has received. Lincoln was far from alone in his use of history. As we have seen, Douglas claimed that popular sovereignty reflected the founders' approach to the slavery problem, and southerners maintained that the founders had deliberately protected slavery in the constitution. These contrasting memories, developed over time and frequently for specific political purposes, illustrate the degree to which the slavery controversy precipitated a sectional struggle over the nation's past as well as its future. The partially mythic character of all of these historical interpretations underscores rather than detracts from their cultural and political significance. Useful studies on this front include Major L. Wilson, "Lincoln and Van Buren in the Steps of the Fathers: Another Look at the Lyceum Address," Civil War History 29 (September 1983): 205-08; Wilson, Space, Time, and Freedom, 120-47, 178-210; John Hope Franklin, "The North, the South, and the American Revolution," Journal of American History 62 (June 1975), 5-23; George B. Forgie, Patricide in the House Divided: A Psychological Interpretation of Lincoln and His Age (New York: W. W. Norton, 1979); and Grant, North Over South, 19-36. 
slavery nationalisms exerted a profound political influence. Certain of their conservative intent, Republicans considered secession not only as a subversion of constitutional order, but also as a perversion of national ideals. By their lights, secession desecrated the democratic process and shattered the Union in order to promote a social system that repudiated the nation's core principles. Imbued with Lincoln's nationalism, Republicans refused to countenance it. Millions of soldiers-and four bloody years of war-arbitrated the dispute. 